\title{
Digenean parasites of the water skipper Euphlyctis cyanophlyctis (Schneider, 1799) (Anura: Dicroglossidae) of the South Western Ghats, India
}

\section{Shinad Keloth and Prasadan Puthanpurayil Kandambeth*}

Ecological Parasitology and Tropical Biodiversity Laboratory. Department of Zoology. Kannur University. Mananthavady Campus. Wayanad- 670645. Kerala. India. *Email: prasadanpk@kannuruniv.ac.in.

\begin{abstract}
Five species of digenean parasites, Diplodiscus mehrai, Tremiorchis ranarum, Halipegus mehransis, Ganeo glottoides and Ganeo tigrinum, of the frog Euphlyctis cyanophlyctis (Schneider, 1799) (Anura: Dicroglossidae) from the Wayanad Region of the South Western Ghats are reported in this paper. Multiple infections were also recorded during the study. Prevalence of infection of D. mehrai, T. ranarum, $H$. mehransis, G. glottoides and G. tigrinum were $12 \%, 8 \%, 2 \%, 31 \%$ and $8 \%$, respectively, and the intensity of infection were 1.7, 34.4, 2, 4.5 and 2.9, respectively.
\end{abstract}

Keywords: Digenean parasites; Frog; Euphlyctis cyanophlyctis; Western Ghats; Prevalence.

\section{Introduction}

Amphibians,

particularly anurans, harbour a variety of adult and larval trematodes involving freshwater gastropods as first intermediate hosts in their life-cycles (Duda and Verma, 1996). The trematode fauna of amphibians of India has been the subject of numerous
Received

September 26, 2018

Accepted

November 11, 2018

Released

December 31, 2018

Full Text Article

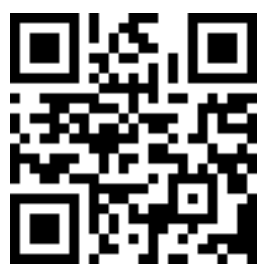

\footnotetext{
ORCID

D) $0000-0002-3876-9697$ Shinad Keloth

(1) 0000-0001-7228-8435

Prasadan

Puthanpurayil

Kandambeth
}

investigations, including those by Mehra and Negi (1926a, b, 1928), Bhalerao (1926, 1936a, b, c, 1937), Srivastava (1933a, b, 1934a, b), Pande (1937), Chauhan (1954), Gupta and Agrawal (1966, 1967), Pandey (1968, 1969a, b, 1981), Gupta (1970, 1977), Mukherjee and Ghosh (1970, 1972), Singh (1977) Janardanan et al. (1987), Janardanan and 
Prasadan (1991), Brinesh and Janardanan (2014) and Shinad and Prasadan (2017a, b, 2018a, b). Singh (1977) made the first contribution to the trematode fauna of amphibians in Kerala. Later Janardanan et al. (1987) recorded Pleurogenoides ovatus Rao, 1977 from Rana tigrina (Hoplobatracus tigerinus) and later Janardanan and Prasadan (1991) elucidated its life cycle. The life cycle of a new species $P$. Malampuzhaensis was established by Brinesh and Janardanan (2014). Recently four new species of digenetic trematodes from amphibian hosts were reported from Western Ghats by Shinad and Prasadan (2017a, b, 2018a, b).

The water skipper Euphlyctis cyanophlyctis (Schneider, 1799) (Anura: Dicroglossidae) inhabits the pools/standing waters in the plains and sub-mountainous areas of the Western Ghats. It is widely distributed throughout South Asia (Frost, 2014). Despite its common occurrence in different types of freshwater bodies, the parasite fauna had not been a subject of any in depth study. During our studies on the digenean parasites of frogs of the Western Ghats, Wayanad Region, an analysis was made on the species composition of digenean parasites of E. cyanophlyctis. This paper deals with the digenean parasites found in E. cyanophlyctis of the Western Ghats, Wayanad Region with their prevalence and intensity of infection.

\section{Materials and methods}

\section{Study area}

The study was carried out in the Wayanad Region of the Western Ghats (latitude $11^{\circ} 27^{\prime}$ and $15^{\circ} 58^{\prime}$ North and $75^{\circ} 47^{\prime}$ and $70^{\circ} 27^{\prime}$ East longitude). Western Ghats is a treasure trove of biological diversity in India and is considered one of the "hottest hotspots" of biodiversity because of its very rich fauna and flora and the highest level of endemism.

Collection localities Birakuppa, Chandhanathodu, Chennalode,
Chooralmala, Chundel, Ammana, Karappuzha Dam, Kavummandham, Makkimala, Ondayangadi, Pakkam, Panamaram, Payyampally, Peechangode, Pulpally, Thalappuzha and Wayanad District.

Period of collection: January 2016 to October 2017.

\section{infection}

Prevalence and intensity of

Prevalence and intensity of infection were measured following Bush et al. (1997).

One hundred specimens of $E$. cyanophlyctis collected during the period from January 2016 to October 2017 from various water bodies using sweep hand net were brought to the Laboratory, maintained in cement cisterns and fed them occasionally with insects. The specimens were narcotized with chloroform, dissected, their skins were removed, and the muscle tissues were macerated to detect the presence of metacercariae. Internal organs were also dissected out from each frog, placed in separate Petri dishes containing 0.75\% saline, macerated and examined under the stereozoom microscope. Adults, when present, were carefully removed, transferred to $0.75 \%$ saline in separate watch glasses and studied under Nikon ECLIPSE Ni-U phase contrast research microscope without supravital staining or after staining with neutral red.

Permanent slides of adult parasites were prepared after fixing them in 5\% formalin under slight cover glass pressure and staining with acetocarmine, following the procedure outlined by Cantwell (1981).

Specimens were measured using the Nikon NIS Elements Imaging software. All measurements are in micrometers $(\mu \mathrm{m})$, as range followed by mean in parentheses. Illustrations were made using the Nikon Y-IDT drawing tube attached to the Nikon ECLIPSE Ni-U microscope and the details were added free hand from observations made on 
live specimens. Photographs were taken with a Nikon Y-TV55 camera.

\section{Ethical approval}

All applicable international, national, and/or institutional guidelines for the care and use of animals were followed. All procedures performed in the study involving animals were in accordance with the ethical standards of the institution or practice at which the study was conducted.

\section{Results}

Five species of digenetic trematodes, D. mehrai, T. ranarum, $H$. mehransis, G. glottoides and Ganeo tigrinum were found infecting the duodenum of the frog E. cyanophlyctis.

Table 1. Digenean parasites with their prevalence and intensity of infection.

\begin{tabular}{|l|l|l|}
\hline Name of the parasite & \multicolumn{1}{c|}{ Prevalence of infection } & \multicolumn{1}{c|}{ Intensity of infection } \\
\hline Diplodiscus mehrai & 12 out of 100 frogs (12\%) & 20 from 12 infected frogs (1.7) \\
\hline Tremiorchis ranarum & 8 out of 100 frogs (8\%) & $\begin{array}{l}275 \text { from 8 infected frogs } \\
(34.4)\end{array}$ \\
\hline Halipegus mehransis & 2 out of 100 frogs (2\%) & 4 from 2 infected frogs (2) \\
\hline Ganeo glottoides & 31 out of 100 frogs (31\% & $\begin{array}{l}139 \text { from 31 infected frogs } \\
(4.5)\end{array}$ \\
\hline Ganeo tigrinum & 8 out of 100 frogs (8\%) & 23 from 8 infected frogs (2.9) \\
\hline
\end{tabular}

Family Paramphistomidae Fischoeder, 1901

\section{Genus: Diplodiscus Diesing, 1836}

1. Diplodiscus mehrai Pande, 1937 (Figure 1)

The genus Diplodiscus of the family Diplodiscidae Cohn, 1904 was erected by Diesing (1836) and ascribed D. Subclavatus (Pallas, 1760) as its type species. So far 17 species have been added to this genus from amphibians. Of these six valid species have been reported from Indian amphibians by Srivastava (1934b) Pande (1937), Bhalerao (1937), Kaw (1950), Pandey and Chakrabarti (1968), Pandey (1969a), Mukherjee and Ghosh (1972), Dwivedi (1977), Singh (1977) and Shinad and Prasadan (2017a). They are Diplodiscus amphichrus Tubangui, 1933, D. amphichrus magnus Srivastava, 1934, D. mehrai Pande, 1937, D. lali Pandey and Chakrabarty, 1968, D. chauhani Pandey,1969 and D. cyanophlycti Shinad and Prasadan, 2017.

Tubangui (1933) described $D$. amphichrus from Rana sp. in the
Philippines. Srivastava (1934a) recorded a new variety, $D$. amphichrus var. magnus from E. cyanophlyctis from UP and Pande (1937) added another species, D. mehrai, from the same host in Kumaon Hills. Singh (1954) regarded D. amphichrus var. magnus and D. mehrai as synonyms of D. amphichrus. Mukherjee (1966) further synonymised D. japonicus (Yamaguti, 1936) with D. amphichrus. Fischthal and Thomas (1968) raised the variety magnus of Srivastava to species rank and considered that D. amphichrus of Agarwal and Singh, (1979) as synonym of magnus and so were $D$. amphichrus $D$. japonicus and D. mehrai. Pandey and Chakrabarty, (1968) and Pandey (1969a) described two new species, $D$. lalli and $D$. chauhani from $H$. tigrina and $E$. cyanophlyctis, respectively and Pandey and Jain (1974) upheld the validity of $D$. mehrai. Nama and Khichi (1973) described a new sub species, $D$. amphichrus brevis from E. cynophlyctis and disagreed to the synonymy of $D$. mehrai to $D$. amphichrus. Srivastava (1982) suggested that $D$. lali and $D$. 
chauhani are synonyms of $D$. amphichrus. Srivastava (1982) also considered that the genus is represented by two distinct species D.amphichrus and D.mehrai in India. Recently a new species, $D$. cyanophlycti was added by Shinad and Prasadan (2017a).

Remarks. The species is characterized by conical, aspinose body with a blunt anterior end and broadly round posterior end. It has a sub terminal and slightly oval oral sucker without oral diverticula and a large posterior sucker at the posterior end of body; it has a small central additional sucker. Its mouth is sub terminal and intestinal caeca is wide, extend along the lateral margin of body up to the level of posterior sucker. It has a single testis at the middle of body and a small cirrus sac behind the intestinal bifurcation. Its eggs are large, oval and operculate.

Twelve out of 100 E. cyanophlictis were infected with $D$. mehrai and the prevalence of infection is $12 \%$. Twenty $D$. mehrai were recovered from 12 frogs and therefore, the intensity of infection is 1.7 (Table 1).

Collection localities: Pakkam, Payyambally, Chundel, Birakuppa and Panamaram, Wayanad District.

A1
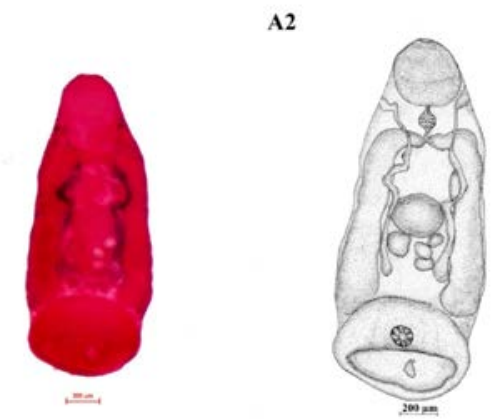

Figure 1. Diplodiscus mehrai (A1 and A2).

\section{Tremiorchis ranarum Mehra and Negi, 1926 (Figure 2)}

Mehra and Negi (1926a) proposed the genus Tremiorchis of the family Brachycoeliidae Looss, 1899 with T. ranarum from $H$. tigerinus as the type species. Ten species of this genus have been reported so far. They are $T$. ranarum Mehra and Negi, 1926, T. mehrai Rai, 1962, T. vitelloconfluentum (Sic) Rai, 1962, T. attenuates Karyakarte, 1973, T. tigrinanum Simha et al., 1974, T. varanum Verma, 1930, T. mathuraensis Swarup and Jain, 1977, T. spinophlyctis Karyokarte and Palladwar, 1977, T. jamshedpurensis Hussain, 1989, and T. jaini Srivastava and Saxena, 1983. Pandey and Agarwal (1981), with due juistification, considered T. mehrai, $T$. vitelloconfluentum, T. tigrinarum, $T$. mathurensis and T. spiniphlyctis as synonyms of T. ranarum. Rajendran and Janardanan (1993) elucidated the life cycle of $T$. ranarum.

Remarks. The species is characterized by elongate - oval body with spines on the surface, except at the posterior third. It has a sub terminal and roughly spherical oral sucker and a ventral sucker at about one - third distance from the anterior end of body. Mouth is sub terminal, pharynx is small and thick walled, oesophagus is long narrow and intestinal caeca terminates just behind the anterior margin of anterior testes. It has a round or transversely ovoid testes and a round ovary. Numerous small eggs are present.

Eight out of 100 E. cyanophlictis were infected with $T$. ranarum so the prevalence of infection was $8 \%$. Two hundred and seventy five $T$. ranarum were recovered from eight frogs and the intensity of infection was 34.4 (Table 1).

Few frogs infected with $T$. ranarum exhibited multiple infections with adult trematodes.

Collection localities: Chundel, Panamaram and Pulpally, Wayanad District.

\author{
Family: Brachycoelidae Johnston, \\ 1912 \\ Genus Tremiorchis Mehra and Negi, \\ 1926
}


B1

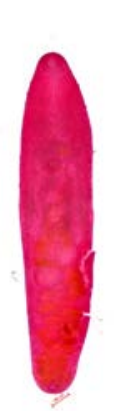

B2

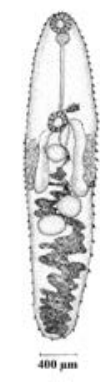

Figure 2. Tremiorchis ranarum (B1 and B2).

Family: Hemiuridae Luhe, 1901

Genus Halipegus Looss, 1899

3. Halipegus mehransis Srivastava, 1933 (Figure 3)

The genus Halipegus was established by Looss, 1899 with $H$. ovocaudatus Vulpian, 1859. Altogether 22 species of this genus have been reported from different parts of the world. The nine species reported from India are $H$. ovocaudatus (Vulpian, 1859) Looss, 1899, H. longispina Klein, 1905, $H$. mehransis Srivastava, 1933, H. mehransis mehransis Srivastava, 1933, H. mehransis minutes Srivastava, 1933, H. spindalis Sruivastava, 1933, H. udaipurensis Gupta and 1967, H. occidualis Stafford, 1905, and H. ambalensis Gupta and Chopra, 1936. Rankin (1944), while reviewing the genus, synonymised $H$. longispina and $H$. spindalis with $H$. ovocaudatus and $H$. mehransis, respectively. Srivastava (1933a) recorded a new variety of $H$. Mehransis, H. mehransis var. Minutum. Bhalerao (1936c) abolished the variety and considered it as a synonym of $H$. mehransis.

Some more species were described under the genus Halipegus from India. Klein (1905) described $H$. longispina from Indian frog. Rankin (1944) treated $H$. longispina as synonym of $H$. ovocaudatus, the type species of the genus. Later Rankin (1944) synonymised both species as that of $H$. Mehransis. Gupta and Agrawal (1967) described $H$. udaipurensis from E. cyanophlyctis and
Gupta and Chopra (1986), H. ambalensis from the same host. Pandey (1975) synonymised $H$. udaipurensis and $H$. ambalensis with $H$. mehransis.

Remarks. The species is characterized by smooth, spindle shaped body with slightly tapering anterior end and a blunt posterior end. Sub terminal, circular oral sucker and large, prominent, muscular ventral sucker. Its mouth is sub terminal and intestinal caeca extend laterally up to hind end of body. Its testes are oval, post-acetabular and obliquely side by side and cirrus sac is poorly developed. Genital pore is median, ventral to pharynx and ovary is post testicular and intercaecal. Uterus with large number of closely packed transverse coils occupy most of the intercaecal field in the forebody.

Two out of 100 E. cyanophlictis were infected with $H$. mehransis and the prevalence of infection is $2 \%$. Four $H$. mehransis were recovered from two frogs and the intensity of infection is 2 (Table 1).

Multiple infection was observed in one E. cyanophlictis with H. Mehransis, G. glottoides and D. mehrai.

Collection locality: Pakkam, Wayanad District.
C1

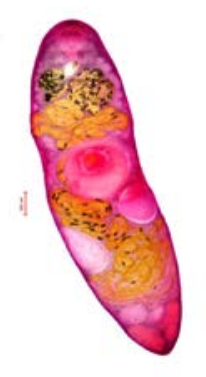

C2

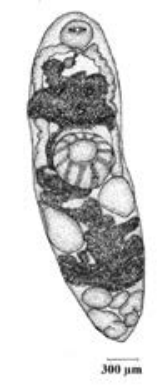

Figure 3. Halipegus mehransis (C1 and C2).

Family: Lecithodendriidae (Luhe, 1901) Odhner, 1901 Genus Ganeo Klein, 1905 


\section{Ganeo glottoides Klein, 1905 (Figure} 4)

The genus Ganeo of the family Lecithodendriidae (Luhe, 1901) Odhner, 1901 was proposed by Klein (1905) with $G$. glottoides as its type from $E$. hexadactylus from Tamil Nadu. Since then 17 species have been added to the genus. They are G. glottoides Klein, 1905, G. glottoides glottoides Klein, 1905, G. attenuates Srivastava, 1933, G. bufonis Fotedar, 1959, G. gastricus Srivastava, 1933, G. glottoidea madrasensis Mehra and Negi, 1928, G. korkei Bhalerao, 1936, G. kumaonensis Pande, 1937, G. punjabensis Gupta, 1954, G. srinagarensis Kaw, 1950, G. tigrinum Mehra and Negi, 1928, G. gazipurensis Pandey and Chakraborty, 1968, G. ankholensis Hafeezullah and Dutta, 1985, G. vitellosinistrum Dwivedi and Chauhan, 1971, G. kawi Dwivedi and Chauhan, 1971, G. bahurai Ghosh and Chauhan, 1982, G. lucknowensis Gupta and Jahan, 1976. Fotedar (1959) while reviewing the genus synonymised G. kumaonensis with $G$. tigrinum. Mukherjee and Ghosh (1970) synonymised $G$. attenuates with $G$. tigrinum. G. kawi and G. gazipurensis were synonymised with $G$. bufonis by Rao (1974) and Gupta and Jahan (1976) respectively. Later Gupta (1977) considered $G$. bufonis as a synonym of $G$. tigrinum. Rao and Kameswari (1976) synonymised G. korkei and G. punjabensis with $G$. tigrinum.

Remarks. The species has an elongate oval body with bluntly pointed anterior end, and broadly round posterior end. Body is covered with small spines which are closely set at the preacetabular zone and gradually decrease in number behind ventral sucker. It has a small, circular, sub terminal oral sucker and a slightly larger equatorial ventral sucker. Its mouth is sub terminal and pharynx is thick walled and globular. It has long narrow oesophagus and intestinal caeca. Its testes are obliquely placed one behind the other in front of ventral sucker and round ovary is just below the posterior testes. Uterus is coiled, filled with oval operculate eggs. Urinary bladder is V-shaped and vitellaria on the lateral margin up to the posterior one - fourth. Cirrus sac is above ventral sucker. Its gonopore opens on the lateral margin just above the position of caecal bifurcation.

Thirty one out of $100 \mathrm{E}$. cyanophlictis were infected with $G$. glottoides and the prevalence of infection is $31 \%$. One hundred and thirty nine $G$. glottoides were recovered from 31 frogs and the intensity of infection is 4.5 (Table 1).

Multiple infection was observed in few frogs with G. glottoides G. tigrinum, D. mehrai, H. mehransis and T. Ranarum.

Collection localities: Makkimala, Peechangode, Kammana, Pakam, Chundel, Panamaram, Chooralmala, Bairakuppa, Kavummandam and Pulpally, Wayanad District.
D1

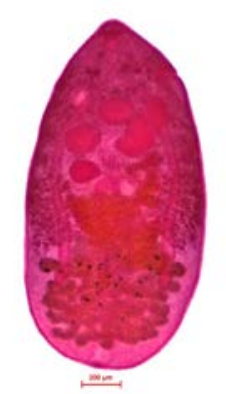

D2

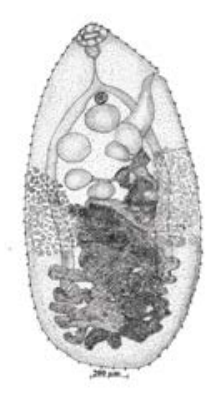

Figure 4. Ganeo glottoides (D1 and D2).

\section{Ganeo tigrinum Mehra and Negi, 1928 (Figure 5)}

G. tigrinum was described from $H$. tigerinus by Mehra and Negi (1928) and from Rana and Bufo species by other workers (Mukherjee and Ghosh 1970, 1972; Agarwal and Singh, 1977). It was also reported from two more hosts, $H$. crassus and Fejervarya sp. by Diengdoh (1989) and Tandon et al. (2001), respectively. Brinesh and Janardanan (2012) described the life cycle of $G$. tigrinum. 
Remarks. The species is characterised by elongate-oval body with bluntly pointed anterior end and broadly round posterior end. Body is covered with small spines which are closely set at the pre-acetabular zone and gradually decreased in number behind ventral sucker. Its oral sucker is small, circular, sub terminal, smaller than ventral sucker. Mouth is sub terminal, pharynx is thick walled, globular, and oesophagus is long, narrow and intestinal caeca reaches up to the upper margin of posterior onefifth. Its obliquely placed Testes are larger than ovary, slightly tandem and located above the ventral sucker. Anterior testis is smaller than posterior testis. Vitellaria are present on the lateral margin up to the posterior one-fourth. Cirrus sac is above ventral sucker and gonopore opens on the lateral margin just above the position of caecal bifurcation.

Eight out of 100 E. cyanophlictis were infected with $G$. tigrinum and the prevalence of infection is $8 \%$. Twenty three G. tigrinum were recovered from eight frogs and the intensity of infection is 2.9 (Table 1).

Multiple infection was observed in a few frogs with $G$. tigrinum, $G$. glottoides and D. mehrai.

Collection localities: Kammana, Pakam, Payyambally, Chundel and Panamaram, Wayanad District.
E1

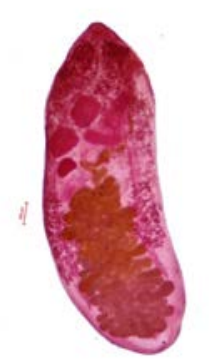

E2

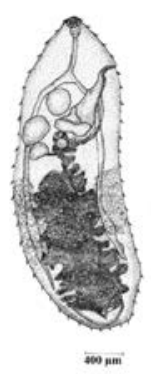

Figure 5. Ganeo tigrinum (E1 and E2).

\section{Acknowledgements}

The authors are grateful to the Kerala State Council for Science, Technology and Environment (KSCSTE), Government of Kerala for providing financial assistance in the form of a major research project (SRS/220/2015/ KSCSTE) to carry out this study. The permission accorded by the Department of Forest and Wildlife, Government of Kerala (Order No WL10-63909/2016) for collecting frogs from the Wayanad forest region is also gratefully acknowledged. The authors are indebted to Prof. K. P. Janardanan for critically going through the manuscript.

\section{Conflict of interest}

The authors declare that that there is no conflict of interest between them.

\section{References}

Bhalerao, G. D. On the trematodes of the digestive tract of a common Indian frog, Rana tigrina, with a description of Centrovitus pentadelphi n.g., n.sp. Parasitology, v. 18, p. 154-159, 1926. https://doi.org/10.1017/ S0031182000005102

Bhalerao, G. D. Studies on the helminths of India. Trematoda I. Journal of Helminthology, v. 14 , no. 3 , p. 163-180, 1936a. https://doi.org/10.1017/S0022149X 00003679

Bhalerao, G. D. Studies on the helminths of India. Trematoda II. Journal of Helminthology, v. 14, no. 4, p. 181-206, 1936b. https://doi.org/10.1017/S0022149X 00004089

Bhalerao, G. D. Studies on the helminths of India. Trematoda III. Journal of Helminthology, v. 14, no. 4, p. 207-228, 1936c. https://doi.org/10.1017/S0022149X 00004090

Bhalerao, G. D. Studies on the helminths of India. Trematoda IV. Journal of Helminthology, v. 15, no. 2, p. 97-124, 1937. https://doi.org/10.1017/S0022149X000307 53 
Brinesh, R.; Janardanan, K. P. Studies on the life cycle of Ganeo tigrinus Mehra \& Negi, 1928 (Digenea). Systematic Parasitology, v. 82, no. 1, p. 13-19, 2012.

Brinesh, R.; Janardanan, K. P. The life history of Pleurogenoides malampuzhensis sp. nov. (Digenea: Pleurogenidae) from amphibious and aquatic hosts in Kerala, India. Journal of Helminthology, v. 88, p. 230-236, 2014. https://doi.org/10.1017/S0022149X130000 84

Cantwell, G. E. Methods for invertebrates. In: Clark, G (Ed.). Staining procedures. Baltimore: Williams and Wilkins, 1981. p. 255-280.

Chauhan, B. S. Studies on the trematode fauna of India. Part. IV. Subclass Digenea (Prosostomata) (A revision of Hemiuroidea from Indian Region). Records of the Indian Museum, v. 51, no. 2, p. 289-393, 1954.

Diengdoh, C. R. Helminth parasite spectrum of amphibian hosts in Meghalaya. Shillong: North-Eastern Hill University, 1989. (Thesis of doctorate).

Diesing, K. M. Monographie der Gattung Amphistome und Diplodiscus. Annalen des Wiener Museums der Naturgeschichte, v. 1, p. 235-260, 1836.

Duda, P. L.; Verma, A. K. Role of gastropods in trematode transmission among amphibians: A numerical analysis. In: Koul, B. L. (Ed.). Advances in fish and wildlife ecology and biology. New Delhi 1: Daya Publishing House, 1996. p. 236-239.

Dwivedi, M. P. Incidence of trematodes in a particular species of frog population. Indian Journal of Helminthology, v. 27, p. 25-32, 1977.

Fischthal, J.H.; Thomas, J. D. Digenetic trematodes of amphibians and reptiles from Ghana. Proceedings of the Helminthological Society of Washington, v. 35, p. 1-15, 1968.

Fotedar, D. N. On a new species of the genus Ganeo Klein, 1905 and some notes on the genus. Journal of Helminthology, v. 33, n. $2 / 3$, p. 151-160, 1959. https://doi.org/ 10.1017/S0022149X00033393

Frost, D. R. Amphibian species of the world. Version 6.0. Electronic Database, 2014. Available from: <http://research.amnh.org/ herpetology/amphibian/index.html.America n>. Accessed on: Jun. 22, 2018.
Gupta, N. K.; Chopra, R. On digenetic trematodes of amphibians from India. Part I. Research Bulletin of the Panjab University, v. 35, p. 1-6, 1986.

Gupta, P. D. Fauna of Rajastan, India, Part 8. Trematoda. Records of the Zoological Survey of India, v. 62, p. 171-190, 1970.

Gupta, P. D. Studies on the genus Ganeoi Klein, 1905 (Trematoda. Lecithodendridae). Records of the Zoological Survey of India, v. 72, p. 281-290, 1977.

Gupta, S. P.; Agarwal, V. Two trematode parasites of Rana cyanophlictis from Udaipur (Rajastan). Proceedings of the National Academy of Sciences, India Section B: Biological Sciences, v. 36, p. 530-536, 1966.

Gupta, S. P.; Agrawal, V. On a new trematode, Halipegus udaipurensis n.sp. from Rana cyanophlyctis from Udaipur. Indian Journal of Helminthology, v. 19, p. 77-80, 1967.

Gupta, V.; Jahan, A. On two new trematode parasites of amphibian from Lucknow. Indian Journal of Helminthology, v. 28, p. 141-147, 1976.

Janardanan, K. P.; Prasadan, P. K. Studres on the life-cycle of Pleurogenoides ovatus Rao, 1977 (Trematoda: Pleurogenetinae). Journal of Helminthology, v. 65, no. 1, p. 43-50, 1991. https://doi.org/10.1017/S0022149X 00010427

Janardanan, K. P.; Shanavas, K. R.; Usha, N. V. On the progenetic metacercaia of Pleurogenordes ovatus Rao, 1977 (Trematoda: Pleurogenetinae) from the freshwater crab, Paratelphusa hydrodromous (Herbst), with observation on its in vitro excystment. Zoologischer Anzeiger, v. 219, p. 313-320, 1987.

Kaw, B. L. Studies in Helminthology. Helminth parasites of Kashmir. Part I Trematoda. Indian Journal of Helminthology, v. 2, p. 67-126, 1950.

Klein, W. Neue Distomen aus Rana hexadactyla. Zoologische Jahrbücher. Abteilung für Systematik, Geographie und Biologie der Tiere, v. 22, p. 1-22, 1905.

Looss, A. Weitere Beitrage zun Kenntniss der Trematoden: Fauna Aegyptens. Zoologische Jahrbücher. Abteilung für Systematik, Geographie und Biologie der Tiere, v. 12, p. 521-784, 1899 .

Mehra, H. R.; Negi, P. S. On a new trematode Tremiorchis ranarum nov.gen, spec., from the common Indian frog Rana tigrina. 
Parasitology, v. 18, no. 2, p. 168-181, 1926 a. https://doi.org/10.1017/S00311820000051 26

Mehra, H. R.; Negi, P. S. The trematode parasites of Rana tigrina of the Family Pleurogenetinae Luhe. Proceedings of the Indian Science Congress, v. 13, p. 185-186, 1926b.

Mehra, H. R.; Negi, P. S. Trematode parasites of the Pleurogenetinae from Rana tigrina with a revision and synopsis of the sub family. Allah Univiversity Study, v. 4, p. 63118, 1928.

Mukherjee, R. P. On some amphistomes of India. Indian Journal of Helminthology, v. 28, p. 94-103, 1966.

Mukherjee, R. P.; Ghosh, R. K. Studies on some amphibian trematodes from Uttar Pradesh and West Bengal. (Part I). Indian Journal of Helminthology, v. 22, p. 61-78, 1970.

Mukherjee, R. P.; Ghosh, R. K. Studies on some amphibian trematodes from West Bengal and Maharashtra (Part II). Records of the Zoological Survey of India, v. 66, p. 273276, 1972.

Nama, H. S.; Khichi, P. S. A new trematode and a new nematode from the frog Rana cyanophlictis Schneider. Proceedings of the Zoological Society, v. 26, p. 15-19, 1973.

Pande, B. P. On some digenetic trematodes from Rana cyanophlyctis of Kumaon hills. Proceedings of the Indian Academy of Sciences - Section B, v. 6, p. 109-120, 1937. https://doi.org/10.1007/BF03051116

Pandey, K. C. On a new trematode Diplodiscus chauhani n. sp. from the common Indian frog, Rana cyanophlictis Schneider. Proceedings of the Indian Academy of Sciences Section B, v. 29, p. 203-206, 1969a. https://doi.org/10.1007/BF03051722

Pandey, K. C. A redisription of Halipegus mehransis Srivastava 1933 from the common Indian frog, Rana cyanophlictis Schneider. Indian Journal of Helminthology, v. 21, p. 109-114, 1969b.

Pandey, K. C. Studies on some known and unknown trematode parasites. Indian Journal of Zoology, v. 14, p. 197-219, 1975.

Pandey, K. C.; Agarwal, N. Further remarks on the genus Tremiorchis Mehra and Negi, 1925. Proceedings of the Indian Academy of Sciences Animal Sciences, v. 90, p. 567-570, 1981.
Pandey, K. C.; Chakrabarti, K. K. On a new trematode Diplodiscus lali n.sp. from the common Indian frog Rana tigrina Daud. Ceylon Journal of Science (Biological Sciences), v. 8, p. 38-41, 1968.

Pandey, K. C.; Jain, K. M. Diplodiscus mehrai Pande, 1937 from the common apple snail Pila globusa Seainson, at Lucknow. Journal of the Zoological Society of India, v. 26, p. 145-147, 1974.

Rajendran, K. V.; Janardanan, K. P. Studies on the life-cycle of Tremiorchis ranarum. Journal of Helminthology, v. 67, no. 2, p. 95101, 1993. https://doi.org/10.1017/S0022 149X00012955

Rankin, J. S. A review of the trematode genus Halipegus Looss, 1899, with an account of the life history if $H$. ampherstensis $\mathrm{n}$. sp. Transactions of the American Microscopical Society, v. 63, p. 149-164, 1944.

Rao, L. N. A note on the synonymy of Ganeo kawi Dwivedi and Chauhan, 1970 with G. bufonis Fotedar, 1959. Current Science, v. 43, p. 285-286, 1974.

Rao, L. N.; Kameswari, M. On the synonymy of Ganeo korkei Bhalerao, 1936 and G. punjabensis Gupta, 1954 with G. tigrinum Mehra and Negi, 1928. Current Science, v. 45, p. 623-624, 1976.

Schneider, J. G. Historia Aphibiorum Naturalis et Literarariae. Fasciculus Primus. Continens Ranas, Calamitas, Bufones, Salamandras et Hydros in Genera et Species Descriptos Notisque Suis Distinctos. Jena: Friederici Frommani, 1799.

Shinad, K.; Prasadan, P. K. Description of Diplodiscus cyanophlycti n.sp. (Digenea: Paramphistomidae) and prevalence and intensity of two other digeneans infecting the water skipper, Euphlyctis cyanophlyctis from the Western Ghats, India. International Journal of Fisheries and Aquatic Studies, v. 5, p. 259-263, 2017a. Available from: <http://www.fisheriesjournal.com/archives/ 2017/vol5issue6/PartD/5-6-5-517.pdf>.

Accessed on: Jun. 22, 2018.

Shinad, K.; Prasadan, P. K. Description of Pleurogenoides cyanophlycti n. sp. (Digenea: Pleurogenidae) infecting Euphlyctis cyanophlyctis from the Western Ghats, India. Journal of Parasitic Diseases, v. 42, no. p. 91-95, 2017b. https://doi.org/10.1007/ s12639-017-0971-x 
Shinad, K.; Prasadan, P. K. Two new species of Pleurogenoides (Luhe, 1901) Travassos, 1921 (Digenea: Pleurogenidae) infecting two species of frogs of the Western Ghats, India. Journal of Parasitic Diseases, v. 42, p. 130136, 2018a. https://doi.org/10.1007/ s12639-018-0978-y

Shinad, K.; Prasadan, P. K. First record of Encyclometra colubrimurorum (Rudolphi, 1819) Dollfus, 1929 (Digenea: Plagiorchiidae) metacercariae from a tadpole and an adult frog of the Western Ghats, India. International Journal of Fisheries and Aquatic Studies, v. 6, p. 135-139, 2018b. Available from: <http://www.fisheries journal.com/archives/2018/vol6issue2/Part B/6-1-20-147.pdf>. Accessed on: Jun. 22, 2018.

Singh, K. S. Some trematodes collected in India. Transactions of the American Microscopical Society, v. 73, p. 202-210, 1954.

Singh, M.S. Studies on the amphibian trematodes from Tamil Nadu and Kerala. Records of the Zoological Survey of India, v. 72, p. 291-294, 1977.

Srivastava, C. B. The fauna of India and adjacent countries. Platyhelminthes Vol. I (Supplement, Trematoda: Digenea). Zoologic Survey of India, p. 1-163, 1982.

Srivastava, H. D. On new trematodes of frogs and fishes of the United Provinces, India. Part. I. Distomes of the Family Hemiuridae from North Indian fishes and frogs with a systematic discussions of the Family Halipegidae and the genera Vitellotrema Guberlet and Genarchopsis Ozaki. Bulletin of the Academy of Sciences of the United Provinces of Agra and Oudh, v. 3, p. 1-60, 1933a.
Srivastava, H. D. On new trematodes of frogs and fishes of the United Provinces, India. Part II. Three new trematodes of the Subfamily Pleurogenetinae (Family Lecithodendriidae) from Rana cyanophlyctis of Oudh. Bulletin of the Academy of Sciences of the United Provinces of Agra and Oudh, v. 3, p. 41-60, 1933b.

Srivastava, H. D. On new trematodes of frogs and fishes of the United Provinces, India. Part III. On a new genus Mehraorchis and two new species of Pleurogenes (Pleurogenetinae) with a systematic discussion and revision of the Family Lecithodendriidae. Bulletin of the Academy of Sciences of the United Provinces of Agra and Oudh, v. 3, p. 239256, 1934a.

Srivastava, H. D. On new trematodes of frogs and fishes of the United Provinces, India. Part. IV. The occurrence and seasonal incidence of infection of certain trematodes of the above hosts. Bulletin of the Academy of Sciences of the United Provinces of Agra and Oudh, v. 4, p. 113-119, 1934b.

Tandon, V.; Imkongwapang, R.; Kar, P. K. Helminth infracommunities in anuran Amphibia of Nagaland, India. Journal of Parasitic Diseases, v. 25, p. 8-20, 2001. https://doi.org/10.1007/s12639-010-00161

Tubangui, M. A. Trematode parasites of Philippine vertebrates, VI. Descriptions of new species and classification. Philippine Journal of Science, v. 52, no. 2, p. 167-197, 1933.

Yamaguti, S. Studies on the helminth fauna of Japan. 14. Amphibian trematodes. Japanese Journal of Zoology, v. 6, p. 551-576, 1936.

License information: This is an open-access article distributed under the terms of the Creative Commons Attribution License, which permits unrestricted use, distribution, and reproduction in any medium, provided the original work is properly cited. 